\title{
Can Christianity and modernity go together?
}

\author{
Est-ce que la foi chrétienne va ensemble avec la modernité? \\ Podem Cristianismo e modernidade caminharem juntos?
}

Rogers Lenaers*

\begin{abstract}
Looking at the question "Can Christianity and modernity go together?" at first glance the answer is no. It has been observed that where modernity grows, to the same extent does religion, nevertheless, the Christian faith is decreasing. The reason is that modern science which developed in Europe has shown since the Enlightenment the certainty that natural phenomena are not the result of divine intervention, but are explained perfectly well by natural causes. Thus discovering the autonomy of the universe and of man, modernity began to walk away from religion, since it is essentially the belief in a Theos, a supernatural being from whom everything would depend, which denies autonomy. So the Christian faith could not enter modernity to save it, although this is its mission. Fortunately Christianity is not by nature a religion: it has become one. By nature it is a faith in Jesus and God, as Jesus experienced it and lived. We cannot free ourselves from all religions, but we can free ourselves from the image of a Theos in order to meet the Absolute Reality which is Absolute Love. The article develops in detail what this demands from us.
\end{abstract}

Keywords: Christianity. Christian faith. Modern science. Reason. Religion.

\section{Résumé}

A la question "Est-ce que la foi chrétienne va ensemble avec la modernité?" a première vue la réponse est non. On constate en effet que là où la modernité se développe, dans la même mesure la religion et donc aussi la foi chrétienne va diminuant. La cause en est que les sciences modernes, qui se sont développées en Europe ont porté depuis le temps des Lümières à la certitude que les phénomènes naturels ne sont pas l'effet d'interventions de la part d'une divinité, mais s'expliquent parfaitement par des causes naturelles. En découvrant ainsi I' autonomie de I' univers et de l'homme, la modernité commençà à s'eloigner de la religion, puisqu'elle est essentiellement la croyance à un Theos, un être surnaturel dont tout dépendrait, ce qui nie cette autonomie. Alors la foi chrétienne ne pourrait pas pas pénétrer la modernité pour la sauver, ce qui est pourtant sa mission. Heureusement le christianisme n'est pas par nature un religion: il l'est devenue. Par nature il est une foi en Jésus et de Dieu, comme Jésus l' a expériencé et vécu. Nous n'avons qu' à nous délivrer de tout ce qui est religion, en quittant I'image du Theos pour rencontrer la Réalité Absolue qui est Amour Absolu. L'article developpe alors en détail ce que celà demande.

Mots-clés: Christianisme. Foi chrétienne. La science moderne. Raison. Religion.

Article received on September 30, 2014. Approved on March 20, 2015. * Master in Theology, especialized in Classical Philology. Parish priest in Vorder and Hinterhornbach (Lechtal, Tyrol, Austria). Country of
origin: Belgium. E-mail: roger.lenaers@gmx.at.

Horizonte, Belo Horizonte, vol. 13, no. 37, p.163-192, Jan./Mar 2015 - ISSN 2175-5841 


\section{Introduction}

Looking at the question "Can Christianity and modernity go together?" at first glance the answer is no. It has been observed that where modernity grows, to the same extent does religion, nevertheless, the Christian faith is decreasing. The reason is that modern science which developed in Europe has shown since the Enlightenment the certainty that natural phenomena are not the result of divine intervention, but are explained perfectly well by natural causes. Thus discovering the autonomy of the universe and of man, modernity began to walk away from religion, since it is essentially the belief in a Theos, a supernatural being from whom everything would depend, which denies autonomy. So the Christian faith could not enter modernity to save it, although this is its mission. Fortunately Christianity is not by nature a religion: it has become one. By nature it is a faith in Jesus and God, as Jesus experienced it and lived. We cannot free ourselves from all religions, but we can free ourselves from the image of a Theos in order to meet the Absolute Reality which is Absolute Love. The article develops in detail what this demands from us.

\section{Videtur quod non (It seems not)}

The answer to this question should begin in the same manner as Aquinas in his Summa Theologica starts his treatment of such questions, i.e. with a videtur quod non, it seems they cannot. Then where the modernity, i.e. the actual western culture, has become dominant, in Europe, in the United States, in Canada, in Australia, in New Zealand, in the same Christianity has dwindled. There is no need of many statistics to prove that. This one will do. Till about 1750 in the western world church attendance still reached nearly the $100 \%$ mark, such as it had been since the Christianizing of Europe had been completed, hence since about the year 1000. But by the middle of the 2oieth century it had fallen to about $65 \%$, what means that in two centuries about $35 \%$ or one third of the church members had said farewell to the churches, had become at least indifferent or had given up the 
faith completely and did no more believe in a God in the highest, had become atheist. It could seem that at a religious earthquake had taken place. In reality, it had not been an earthquake but a kind of so-called bradysism, i.e. the slow but continuous raising up of the earth crust that makes that after a time buildings begin to collapse. Likewise in the course of two centuries the western culture, pushed by the evolution of the cosmos, had changed slowly but continuously and had lost her once religious nature.

The roots of that fundamental change were the humanism of the $15^{\text {th }}$ century, kindled by the rebirth of the ancient Greek-Roman culture, that itself had been kindled by Byzantine scholars, who had sought refuge in the West after the Turks in 1453 had besieged and conquered Constantinople. That ancient GreekRoman culture that came back to life in the renaissance, was like all ancient cultures a religious culture and did not undermine the Christian worldview of the West. However, it meant also the rediscovering of the scientific culture of ancient Greece. That rediscovery produced already in the 16th century a number of famous scholars such as Copernicus, Mercator, Justus Lipsius, van Helmont, but it was the 17th century that laid really the foundations of the modern sciences. For that century was that of geniuses such as Galilei, Torricelli, Kepler, Newton, Descartes, Pascal and many others. All of them were convinced Christian believers. Science and Religion were still friends. Nevertheless, religion was not any longer the undisputed queen of the sciences.

Things changed radically in the second half of the 18th century, first in France, that was at that time the think-tank of Europe. A group of French scholars began to draw the consequences of the new ideas that there and in Britain had already germinated for some time. Reason became more important than religious belief and, consequently, where these two conflicted - and the two conflicted more and more often - reason prevailed. That showed that a new worldview was emerging, the modernity. 
The church leaders saw too well that those new ideas were hardly to reconcile with the traditional religious conceptions and that they menaced to undermine their authority and their privileged position in the state. Therefore, they attacked and condemned vehemently that new worldview. Nevertheless, by doing so, they cut themselves and the Christianity of from the enrichment modernity promised. Because of this blindness, the churches lost already in the 18th century the adhesion of a great part of the intellectual elites, who turned away from a religion that rejected human values and scientific certainties. In addition, in the 19th century by neglecting the aspirations and protests of the proletarian victims of the industrial revolution, they lost a great part of the working class that turned socialist and anticlerical. That explains the situation in about 1960: of the former church members, two thirds were gone, even lost forever.

However, since that time the number of the remaining members has not stopped to drop, and to drop even much faster than before. Why much faster than before? Because till to the first half of the 2oth century the church leaders had still succeeded in preserving their faithful more or less from the contact with the modern ideas. They had managed that by organizing and promoting a catholic press, a catholic party, catholic labour unions, catholic social and cultural organizations and institutions, and especially a network of catholic schools, run by priests and nuns, in order to instil into the pupils the catholic ideas and convictions. However, in the half century between 1960 and 2010, the modern media of communication developed in a frantic tempo and soaked the whole society, and the church members, with the ideas of the modernity. The former measures of prevention became totally ineffective. Moreover, those modern ideas obviously pleased more and seemed to promise more happiness than the church doctrine. In addition, in a half century church attendance fell in Europe from $65 \%$ to about 10 to $15 \%$, an incredible plunge down for an institute that had been in the past so dynamic, that it had spread over the whole world. And that number is dropping further, because the elder generations, who form the chief part oft he remaining church population, die slowly away and the younger people, who have grown up in the modern culture and have been modelled by it, show very little 
interest for the realm of religion, so they stay away from the churches. Statistically in still another half century, Christianity in the western world will almost be wiped out

This is not only almost inconceivable, but means also a terrible lost for the whole humanity. For despite the human deficiencies that stick also to the Christian faith, as stemming from the cultures in which it inculturated itself, such as greed, cruelty, lust of power, contempt of the feeble, lack of true humanism, it still remains the guard of the rich visions and the creative lifestyle of the community that is born from the faith in Jesus and shows the way to a new and human world.

\section{The roots of this antagonism}

Undoubtedly, modern culture and Christianity drift away from each other. The question is why. What are the deeper roots of their antagonism? To find them, we should go back to the origins of religion. These coincide with the humanisation process. For although the forbearers of the homo sapiens, the primates, have already attained a certain degree of intelligence and of ethics, they do not have religion. Religion must be the fruit of a further evolution that the primates had missed. Humans knew fear no less than the primates do and tried like these to escape from the dangers that menaced them, but in contrast to their forbearers they tried to understand what happened to them, they asked questions, sought answers, and not finding those in the visible world, they sought them spontaneously in an invisible world high over their heads. For the inexplicable and most menacing phenomena, such as lightning and thunder and hurricanes came from there. However, deep in their psyche humans must have had and have still, engraved in them, a veiled consciousness, a very implicit feeling of a reality that transcends them, without which religion were never born. The occasional confrontation with the often terrific, sometimes beneficial, natural phenomena, that transcended them as well, awoke that sleeping conscience of a transcending 
reality, and the combination of the two gave birth to the representation of humanlike supernatural beings, narrowly linked with those phenomena, hence of gods of lightning and thunder, of rain, of storm, of fertility, of sexual passion, of warfare. Toward those they behaved themselves spontaneously as they did towards the social powers from which they depended, such as father, mother, chief, leader, they honoured and even venerated that invisible powers, praised them, implored their help or their mercy, thanked them, tried with presents to gain or to regain their favour. This enumeration lists all the essential elements of religion. Hence, religion is the collective expression of a worldview that sees all things as depending from humanlike powers in an invisible world. Like human powers, these too can be terrifying but also occasionally kind, they can meddle at will in our affairs and we can enter in contact with them by praying and offering them gifts.

This worldview is called theism, either polytheism, when those powers or gods are conceived of as multiple, or monotheism, when that multiplicity has melted into a unity. Therefore, has it been since our forbearers, the primates, driven by the mysterious impulse of the evolution, have crossed the threshold of humanity, i.e. perhaps since a million years. That means that this worldview has had more than ample time to enter so deep in the human psyche that it has become nearly indelible.

But the fast progress of the sciences in the 17th century had lead in the 18th to the discovery that many of the enigmatic and inexplicable happenings had been mistaken for an intervention of gods or God out of a supernatural world, whereas they were perfectly explicable with the aid of the natural laws of this world, discovered progressively by the modern sciences. Because of these discoveries, the need of an intervention of God to explain what happened waned. Whereas before everybody had meant to see God intervening in lots of events, at the end they did not see him any more. Bit by bit people forgot him; he became superfluous, at the end even improbable. In addition, as the sciences proved finally the impossibility of extra cosmic interventions in the natural order (the cosmos would collapse, if only one of its laws was infringed), it became easy and soon normal to deny the 
existence of that invisible and inactive Being, that could not even prove its reality. Consequently, theism seemed not any longer meaningful, for there was no Theos, no God in the highest. Therefore, the modernity became a non-theistic culture, the only one in the whole history of humanity. Even today that western worldview is only an isle in an ocean of religious fervour. One ought only to look to the Islamic countries or to India.

However, if Christianity is a religion, i.e. a form of theism and modernity is explicitly non-theist, atheist, the two not only seem to exclude each other: they exclude each other really and even necessarily. If this is true, our Christian message of salvation cannot penetrate in that culture and impregnate it, and that were catastrophic both for the church and for the modernity. For the church could not succeed in doing that for what she exists and to what she is sent: to transform the world, hence also the modern world, into the Reign of God, and she could no more even justify her existence. In addition, the modern western culture, of which the deficiencies and problems are blatant, together with the whole humankind that becomes slowly infiltrated by the ideas of the modernity could not be healed by the salutary influence of Jesus.

\section{Sed contra est quod}

But there is an escape from that menace. For by Thomas after the videtur quod non and after the arguments that seem to prove that, follows always the sed contra est quod, "against it stays" and then he develops the opposite position, the right one. Indeed, from that menace there is an escape, but the price of that escape is very high and the major part of the church, to begin with the hierarchy, will not be willing to pay a so high price. Christianity should namely stop to be theistic, to be a religion. On that condition, but only on that, the conflict of faith and atheistic western culture can end. For atheism is in itself not a denial of transcendence, it is only the denial of the existence of a Theos, an instance in a supernatural world, 
from whom all depends, who could impose us its laws and who would rob us so of our autonomy.

But does that condition make any sense? Is Christianity not essentially a religion? No, it is not! It has only in the course of time become a religion. Originally and essentially it is the community of those that let themselves lead by their faith in Jesus of Nazareth, because they recognize in him the immortal revelation of the Ultimate Mystery, or formulated in pre-modern words: in Jesus Christ as the eternal Son of God. This community has soon given up the Jewish religion from which she had risen, with its traditions such as circumcision, food precepts, sacrifices, prohibition of labour on Sabbath, Jewish rites and Jewish holidays. But growing and developing itself in an other deeply religious environment, first that of the Hellenistic, later that of the German and the Slavic polytheism, it became on her part a religion, i.e. it assumed all the elements that characterize religions, such as, priests, sacraments, holy books, vows, temples, prayers. Whereas in he first two centuries it had not known sacrifices, from the 3rd century on the Eucharist became regarded as a sacrifice, in order to appear a true religion like the others. But in its essence is not at all a religion, it is a faith in Jesus, i.e. an attitude of devotion toward Jesus of Nazareth. While it is not essentially a religion, it can abandon all that it has by and by assumed from religion, and in the first place theism, that is the root of it.

The churches should therefore abandon their image of God as a Theos, an almighty Lord in the Highest, that can intervene at will in the human affairs and from which we can get help, if we beseech him. They should instead develop a nontheistic image of God, that is not any longer incompatible with the non-theistic (or a-theistic) worldview of the modernity. But is such a non-theistic image of God conceivable? Yes it is.

To develop such an image, we can start from a saying of the atheist Albert Einstein: "To be aware that behind all we can experience, something is hidden, that our intellect is unable to catch, something of which the beauty and the majesty 
come only imperfectly and as a feeble shine to us, to be aware of that, is true religiosity. In that sense am I a deeply religious atheist." If it can be made plain that this nameless non-theistic "something" is wide enough to absorb the two basic elements of the Christian image of God, that are: Creator and Father, then nothing more will stay in the way of the reconciliation between the atheistic modernity and the non-theistic faith.

First to Creator of heaven and earth, i.e. of all that is. Precisely that idea seems to block utterly every attempt of conciliation between modernity and faith, for it stresses the absolute dependence of the cosmos and cements so the denial of our autonomy. But that's a bridge to far. For to create does not at all mean to produce. Machines produce, but cannot create. To create means to express its own interiority in the materiality. Just that is what the creative artist does. His creations are his spiritual self that takes a material form. If we then interpret the cosmos as the slowly evolving self-expression of an absolute Spirit, there is no more opposition, only distinction, between "God" and the cosmos. For if "God" means not any longer an extracosmic instance, but the spiritual Depth of all that exists, even our liberty and autonomy belong to this self-expression. When we than conceive of that Something that hides behind and in in all things, as a selfexpressing Reality, we are already very near to that what modern Christians mean, when they say "God".

But the authentic Christian tradition, that we should not give up, calls that wonderful and creative Something also "Father". As followers of Jesus, who often called the Mystery in which we live by that name, we too should do that. And he called it by that name, because his deep mystical experience of that Ultimate Reality evoked in him in a transcending degree what he had experienced as a boy in his contact with his father: unconditional care, but at the same time unchallenged authority. Sure, "God", the Ultimate Reality, that he experienced as absolute love to him and absolute appeal on him, was not really his father, but was for him (and for all people, even for the whole creation) like a father, and he was like his son. 
$\mathrm{He} / \mathrm{She} / \mathrm{It}$ was loving him, he knew for sure, and was prodding him always to love, whatever it costed, because the Ultimate Reality is also the Ultimate Love. That Ultimate Love dwells not in heaven, but in the heart of all that exists und pushes all things incessantly to evolve, and pushes us, humans, to become more human, more love. That "Something" therefore is an absolute "Thou", that says "thou" to us.

Only on the condition that we think about God in that new manner, we can be at the same time truly faithful and truly citizens of the modern world and "inculturate" our faith in that modern world and be in that way a source of healing for that modern world. Therefore we should avoid to speak of "God". For in the ears of the no more theistic western world, that name evokes always the Theos of the tradition, and so denies our autonomy and is therefore a red cloth for every true atheist. But by ourselves we can still pray to "God", conscious that this appellation means no more the pre-modern Theos, but the loving Mystery, the wonderful Something that reveals itself in every thing and in us and of which the most radiant image is the very model of love Jesus of Nazareth.

As has been said, the price of leaving the traditional theistic image of God for a new and non theistic image is high. We must indeed change our course and take leave from apparent but deep grounded evidences and certitudes and must learn to take self decisions, instead of accepting and doing what has been ordered by the religious authorities and that all people are doing. And that is very difficult.

\section{A farewell to the formulation of the creed-}

Which changes are most necessary? First of all the creed ought to be formulated anew. For by abandoning the theistic image of God that the Christian tradition has inherited from the millenarian history of the human race, the modern faithful can not any longer confess with the creed that Jesus is the only begotten Son of God, born before all centuries from the Father (for how could humans know that?), that has descended from heaven (for there are no more two realms, ours and that of God, and hence no passing at all from the one to the other), and that he has 
risen from the grave and has ascended into heaven (for that contradicts flatly all the laws of nature) and will come back to judge us and everybody. Put briefly, the confession that Jesus is God of God, true God from the true God, and which since the council of Nicea has become the central pillar of the Christian faith, cannot more be held.

There are still more grounds that force us to give up the creed in its Nicene formulation. Iin the modernity every statement has to prove that it rests on controllable bases, not on mere beliefs. But how could ever be proved that a human is at the same time the all transcending God? And how could be the psychology of a human, who necessarily is limited and marked by a particular culture and hence can get wrong, but who at the same time should be the almighty and all knowing Theos? Moreover we should not forget that in the first half century after his death, Jesus has clearly not been regarded and venerated as (a) God. The Nicene dogma, that Jesus is true God from the true God is thus a later development, brought about by historical causes, and is in some sense even a deviation form the original faith.

But by what should that Nicene dogma be replaced, so that Jesus can remain the centre of our existence and the source of our salvation? By the confession, based on his deeds and words, that in him the Ultimate Love has revealed itself in a most expressive way. That indeed is the heart of our Christian faith. We should not expect another saviour, he is for us the Alpha and Omega. We have only to follow him.

But this Nicene dogma is only one article of the creed that clearly supposes a theistic image of God. There are some more. First the virgin birth of that saviour of mankind. Indeed, the two tales of the conception and birth of Jesus, in the gospel of Matthew and that of Luke, deny explicitly the role of a male partner that for a conception is biologically necessary. Thus the mother of Jesus would have remained a virgin. His birth should then have been a case of parthenogenesis. But in the family of the mammals, to which we, humans, belong, parthenogenesis is 
unthinkable. Moreover the lack of the fecondating male semen would have as consequence that in the zygote the chromosom pair $\mathrm{XY}$, that is constitutiv for the male sex, would fail. The foetus in Marys womb would posses only the XX-pair, so that Jesus would be a girl. That matter-of-fact conclusion, to which the modern sciences lead, can seem blasphematory and heretic. But if we reject the absolutely reliable scientific conclusions, we cannot longer hope to harmonize faith and modernity, and for both parts this would be catastrophic.

But in the case of the virgin birth we encounter only the pre-modern, prescientific formulation of a real experience. The followers of Jesus have experienced that he was not like everyone of us, egocentric, faulty, disappointing, that in hem a new and wonderful kind of humans was born, a new creation, because pure selfexpression of God. If a son bears the traits of his father, Jesus did bear much less the traits of the man who had fathered him, than those of God himself. Thus, with before their eyes the adult Jesus, whom they announced, both evangelists ascribe his conception in a kind of retrospective look not to a man, to flesh and blood, but to the creative activity of the Spirit of God, expressing so that the whole life of Jesus from its beginning on, had been connected with and conducted by the Spirit of God. In the biblical tradition indeed the Spirit or Breath of God, is the creative force that fills the universe with life and renews it and pushes it forward to its perfection. The plenitude of life that the followers of Jesus experienced in him, is the reality that underlays the mythology of his conception without human semen. Understood in that manner, that article of the creed can be accepted by every modern person, either faithful or even atheist.

\section{The impossibility of the bodily resurrection}

But this adult Jesus has been already dead for fast 2000 years! How could he be the source of our salvation today? For that supposes that he can reach us and that we can reach him. The answer of the tradition to that objection is based on a fully theistic image of a God for whom nothing is impossible. That answer is the 
resurrection of Jesus: the third day after his death he has risen from the grave. But everyone that has gone to school, knows today that the human brain, after being deprived from oxygen for less than a quarter of an hour, begins to decompose and soon cannot more organize and steer the functions of the human body. And that after 24 hours it has been irreparably reduced to a useless mass of further decomposing cells. Hence it is utterly unthinkable now that a dead person could ever return to life: he lacks the brain that therefore is indispensable. Likewise as to admit the virgin birth of Jesus is to admit his bodily resurrection a denial of the scientific truth, and that denial makes the integration of the faith in the modernity impossible.

How does the modern faith (i.e. that faith that has left the theistic image of God and its mythology) for that of the Ultimate Love that expresses itself in all that exists, solve the problem, that on the one hand the modernity to which he belongs, cannot admit the miracle of the resurrection of a dead person, and that on the other hand this article of faith, together with that of the divinity of Jesus, is the heart of the Christian confession? Paul indeed emphasizes this in 1 Kor. 15 by stating several times in a few verses that without the resurrection of Jesus the Christian faith, to the grand damn of the faithful, collapses utterly.

The modern faith solves this antagonism in the same manner as the problem of the divine nature of Jesus: by looking for the experience that is hidden behind the formula. This formula shows clearly the influence of the time in which it came into being and does therefore not remain unchanged for ever and ever, but be replaced, if necessary (and now it is necessary), when the times change profoundly. Which experiences lay at the base of the image of resurrection? The experiences of the Jewish people that they were the object of the never lasting care of the transcendent Power, that they named Yahweh, and that promised and gave life to his faithful. They spoke even of a Covenant between Yahweh and them. The inspired prophets dared even to speak of a love-story, a marriage. These images expressed their certainty, based on experience, that Jahweh rewarded his faithful 
worshippers with happiness. But the cruel persecution of their Jewish faith in the 2nd century B.C. by Antiochus Epiphanes showed them that fidelity to Yahweh could bring instead of life torture and death. Their unbroken trust in Yahweh gave them the confidenc that he would give the victims promised life in an other form. But as the Jewish cultur was not a compound of an immortal soul in a mortal body, but a unity, the whole person should be given a new chance. The new span of life the victims should get, would therefore be corporal and earthly But as Jews did not cremate their dead, but laid them in the earth, as if they slept, arose the representation that Jahweh would awake them on his day and that they would get up. The idea of resurrection was born. But this idea supposes that we accept as valid and timelessd a set of timebound convictions and customs, such as the Jewish concept of the human person, that differs from the dualistic concept of the hellenism (that itself is also timebound), and the Jewish manner of burying, and above all their pre-modern, and hence theistic image of God. For without a God for whom nothing is impossible, the return to life of a dead and alread decomposing body, is unthinkable. If we don't say farewell to that image of God, we will never be able to replace the concept of resurrection by one that for the modernity is accessible.

\section{$6 \mathrm{~A}$ modern approach to the so called resurrection of Jesus}

An approach to a non theistic image of God, that renders possible to speak in a modern way of the event the biblical tradition has called resurrection, has been made already above. To resume it briefly, God is the Ultimate Love of whom the cosmos is the evolving self-expression. This self-expression culminates in the selfless love that emerges in the human species and above all in Jesus. For by loving to the limit and abandoning for that everything, even his life, Jesus has become fully one being with that Eternal Love and participates fully in its creative power. And therefore, just as we can say of God that he lives without measure, being the Source of all life, we can say also that Jesus lives, no more in a biological but in an existential way and that we can reach him and that he can reach us und 
let us participate in his fullness. That is the modern answer of the question above how a man who is dead for already 2000 years can still reach us today and inspire and move us and be so our saviour.

Therefore we should have care to replace the theistic formula of "resurrection" for instance by that of achievement, or of final transition in the Ultimate Love, or of becoming one with God, even by eternal life, if eternal is not unterstood in terms of time, as never ending; eternal life means here: achieved life, fullfilled life, life that shares the unconceivable essence of the Ultimate Love.

But 2000 years of tradition and 1500 years of repetition in our churches of the literally taken expression "resurrection", have caused the illusion that this is the exact description of what happened to Jesus in (or after) his death. And so, although it says in other words just the same as the old term resurrection, for most Christians it will be very difficult to agree to that new way of speaking. Surely it is much more abstract than that of a bodily resurrection of Jesus with its oft touching trail of apparitions. What can we answer, whenn they ask us then what the gain is of speaking in those new terms? That it makes our Christian message not any longer inaccessible for all modern humans that are at least a little bit acquainted with the sciences.

But if resurrection is only a mythological word for the renewing effects of loving, Jesus cannot be the only one that has resurged. Of every human, according to the degree of his love, we should than say that he resurges in his death. With this statement we meet St Paul in his letter to the Romans 9:28 [add here the Spanish translation of that verse]. The more we let influence us by him, the more we participate already now in that fullness of life, that in mythological and even misleading terms is called his resurrection.

So appears also more clearly the intimate connection that Paul in 1 Cor.15 stresses so strongly between the resurrection of Jesus and that of the faithful. If Jesus is not ressurrected, he repeats there several times in that few verses, then 
neither we, and if we don't resurrect, neither he. Therefore he can call the resurrected Jesus the firstborn among many brethren (and, of course, sisters). He is the firstborn, because his love superates a long way the love of us all, but we all take part, according to the degree of our love, in his unity with the Primordial Love. Whereas he loves and lives in a transcending measure, wo do that in the measure of our human insufficiency.

\section{7 ... and to the resurrection of the dead}

All this all applies at any ratev $\mathrm{n}$ the first place for those that we call the saints. To venerate them means indeed to confess them as living and inspriring, and therefore as resurrected without even the slighstest idea of an empty grave. Their "resurrection" is the fruit of their unity with the living Jesus, of having part in his attitude and his mind. We have allways known that they live beyond their death, that they over-live, survive, their death. For we have never venerated their soul, even wenn we pelgrimated to their tombs, where their bodily remains are buried, we venerated themelves. And when a saint appeared (of Mary it is said that she has already appeared in several places) those who have seen her or him, have never doubted that they saw the saint himself and not his/her soul.

But what applies to the saints, applies to everbody who has let lead himself by love. For the Primorial Love that is God, pushes everybody towards loving his fellow men. The saints distinguish themselves from the common Christians less by their long payers or their penances or their mystical experiences, than by this, that they responded in an eminent degree to the impulses of God who orientated them to their fellow humans. But as everyone lets move himself at least a little, little bit by the love of his fellow humans, in the same degree everybody "rises from death", i.e. survives death.

But to be moved by love, it is not even necessary to know Jesus and his message, although to know him and to be attracted to him and to follow him, is a very precious help to grow in love. Indeed, also outside of every Christian context 
we meet men and women that are wonder of selfless love. Like of the Christians saints, we can say of people that live in that manner that in their death they experience resurrection. In the case of sages as Socrates, Buddha, Kon-fu-tse, LaoTse their renewing and healing influence in the course of human history renders even visible for all eyes that they live. From dead people does not sprout life, inspiration, renewal as it does from them. But because they have lived outside of the Christian traditions and representations, we will not easily speak of resurrection. We are wrong. We should not confine resurrection (not understood in the mythological way, but as becoming one reality with he Primordial and Eternel Love), to the Christian part of mankind, for compared to the whole of humankind in time and space, Christians are only an insignificant minority. Indeed to confine "resurrection" to that minority would represent God as a biased ruler, and would contradict so our own Christian confession that He s the all encompassing love. Indeed.

That view throws also a new light on the last article of the creed, the resurrection of the dead and the eternal life. For modern people this article is stunning and almost ridiculous. The billions of people that have in the course of millenia been decomposed into their molecules and atoms, should all of a sudden be recomposed and rise up, living and well, with flesh and bones and skin and hair. So the traditional church has always thought. The famous frescoes of Luca Signorelli in the Dome of Orvieto are a colourful illustration of this impossible belief. Where and how that billions could come together to be judged, is of course another insoluble problem. Here appears in which deadend it leads, if one takes literally the visionary decriptions of the Bible that have inspired the creed. But all these disconcerting ideas proceed from the belief in a Theos for whom nothing is impossible. From its fruits one can judge the quality of the tree.

But if we understand resurrection in a modern way, as to live through death in the measure of our love, which is the same as the measure of our participating in the Ultimate Love, disappears that dead-end and the accompanying irritation and 
anger. For then everybody. lives through death more or less, according to the development of the divine germ of love in his depth. And resurrection of the dead is than identical with the eternal life, the final words of that last article of the creed.

If we understand resurrection in that modern way two other mythological articles of the creed appear in a new light, that for modern faithful makes sense. Heaven being used in the Bible as a reverential password for "God", so as to avoid using that holy name, the ascension of Jesus to heaven (since the first Sputnik easy to ridicule) becomes identical with his being absorbed in the Ultimate Love. On the other hand his coming to judge, Last Judgment, that has since the Middle Ages been a source of black terror and panic (as is testified by the Dies Irae), can then easily be understood as his appearance in the world through the community that lets guide its way of life by his inspiration. This way of life makes clearly visible that which is good and that which is bad and pronounces in this sense continually not a condamning or acquiting verdict, but an enlightening judgment.

\section{Consequences for the church doctrine}

So far as for the creed. But on its theistic formulation the whole church doctrine is based. The whole of it should therefore be examined, and much of it would appear as being outdated and calling for a modern reformulation. But because of the limited size of this article, can that only be done here for some of the statements and convictions of that doctrine. Only the following ten points will be treated

\section{a. The marian dogmas and the confession of the Trinity.}

First of all for the statements and traditions that flow directly from the Nicene dogma that Jesus is "true God from the true God" become meaningless. Therefore we should stop calling Mary "Mother of God". She is simply the mother of Jesus of Nazaret. But with the farewell to that first marian dogma collapses also the dogma of her conception without original sin, promulgated in 1854 and that of 
her bodily resurrection and assumption into heaven, promulgated in 1950. They cannot be replaced by a modern formultion. Their contant s simply too premodern.

Moreover even the doctrine of the Trinity, as it is understood commonly, and that means: commonly misunderstood and misrepresented as the confession of three equal Gods, cannot longer be held. To be sure, in a modern view remains unchallenged the confession of God as the Creator of heaven and earth, understood as the Ultimate Love, that in the course of the cosmic evolution expresses and reveals itself progressively, first as matter, then as life,then as conscience, than as human intelligence, finally as selfless love in Jesus and in those in which Jesus lives on. Further the confession of Jesus as his most perfect self-expression. And finally the confession of the Spirit as the vivifying activity of that Ultimate Love.

\section{b. The Bible as a book with "words of God".}

But there is much more that should change, if we have to take leave from theism and hence from the organised form of it: the religion. First our attitude towards the Bible, for all the statements of the creed are based on that Bible. But the belief in holy books, that should have come from God in the highest and therefore are considered as unfallible and binding, is a typical trait of religions. The church also considers her Bible as a book of supernatural revelations and calls it the "Word of God". As faithful Christians that belong to the modernity we need a new approach to that "holy book". For we can not any longer call the Bible word(s) of God. Why not?

Because words are the result of human speaking. and of the Ultimate Reality we cannot say any longer that it can speak. A speaking God is a fully anthropomorphic being. Indeed, to be able to speak one needs a human physiology with lungs, vocal cords, mouth tongue etc. Moreover it supposes a human language system and every such system is depending from human conventions. To ascribe 
that all to God, is robbing him of his a absolute transcendence Why the primitive church has nevertheless thought so? Because she consisted of Jews. And these considered the Bible as the collection of words that Yahweh had communicated or even dictated Moyse and other prophets. Because of our belonging to the modernity we cannot any longer think as they thought. Moreover the behaviour of Muslims and orthodox Jews, that still consider so their holy books and refer to them to justify inhuman deeds, shows too clear to which problems such a belief can lead.

We as modern faithful can cannot longer say that God speaks, we can only say that the Ultimate Love expresses itself, for that is the modern way of understanding creation, this self-expression being the evolving cosmos, that culminates in man and finally in Jesus. Therefore is the Bible for us not a book with unerring words of a Theos in the highest and cannot any longer serve as the absolutely sure base of doctrinal statements or of the liability of personal ideas and it makes no sense to weigh and discuss every word of it.

What is then the Bible for the modern faithful? A book with words of humans, but in which mystically gifted authors have tried to express their intense experience of the transcendent Wonder. For that Wonder continuously expresses itself in the cosmos and especially in those human minds that are receptive for it. But human minds are always minds with personal and cultural limitations and these adhere to their words, and are a source of deficiencies and even errors. Because of this mixture of divine inspiration and human deficiencies and because of the deep cultural gap between those authors and the modern readers, and because the frequent misunderstandings that arise from that gap, we should read the Bible with a critical mind. One could compare it rightly with a goldmine, for a goldmine means concretely: tons of useless stones and grit, and therein often some ounces of gold. That's true also for the Bible. Because of this gold, and despite those tons of grit, she remains fur us holy. At the same time she is the safe reference for making out (that applies in the first place to the New Testament) if something lies still within the limits of our Christian worldview and what lies already outside of it. 


\section{c. The Ten Commandments.}

A third consequence of abandoning theism and hence religion, is a farewell to the Ten Commandments. If the Theos, that celestial lawgiver and punishing (or rewarding) judge, disappears, then disappear with him also his commandments, the biblical ten (the Jews have 318), that formulate in reality the ethical experiences of the Jewish people, and those made by the church that refers to that Theos. These ethics of law need absolutely to be replaced. Even Nietzsche in his parable of the fool who prophesized the total collapse of the western culture as a consequence of the "death of God", saw that most urgent necessity.

What will take the place of the ethics of law? The ethics of love. For the Ultimate Reality pushes us to love and this pushing is the really absolute imperative. In this ethics the good is not any longer that which corresponds to a law, but that which is born out of love and in the measure that is born out of love.

These new ethics will to a large extent coincide with old ones, for these also proceeded from the impulse of the cosmic evolution, that itself is the progressively purer self-expression of the Ultimate Love. This ever active impulse explains that the ethics progress towards humanisation. To the manifestations of that progression belong for instance the ban on slavery, torture, oppression, the proclamation of the absolute rights of the human person, democracy, the equality of the sexes, tolerance, all of them forms of ethical progress, accepted also however reluctantly, by the church leaders in Rome.

But the new ethics will differ clearly from the traditional church ethics on sexuality. These have been indeed formulated and imposed by celibates, tabooing each form of sexual lust outside a sacramental marriage and many forms of it within such marriages. But in the new ethics the norm to observe is not any longer the law, work of humans that ascribe their own decisions arbitrarily to the will of a Theos. It is now selfless love. This has of course important consequences for 
homosexuality, premarital sex or remarriage. The soon coming Conference of Bishops in Rom, will show in how far the church leaders are ready to welcome these new ethics.

\section{d. The ecclesiastical power structure or hierarchy.}

A fourth consequence of abandoning theism and hence religion, is the necessary farewell to the ecclesiastical hierarchy. Indeed, the new image of God means the end of every institution that justifies its claims with a mandate from a Theos, a God in the highest. In the modernity authority does not any longer descend from invisible powers in the highest, because there are no more such powers. How by the way could anybody prove that the mandate he claims as coming from the Theos, is not a fake? In the view of the modern faith authority rises now from the depth of the human reality in which the Original Love expresses and reveals itself. That means that no pope or bishop can claim, more than any other faithful, a right to teach and govern, the so called magisterium. For whence would they have that magisterium? Texts in the New Testament to corroborate their claim, are of no help, for those texts are not infallible "words of God", but express only the honest views of pre-modern believers, for which all was coming from the high.

But must this farewell to the hierarchy and its magisterium not inevitably lead to arbitrariness and chaos? By no means. For every human community, surely also that one that has sprung from the radiation of the risen Jesus, produces spontaneously the structures it needs. Also the indispensable structures of authority. But those who in the community exercise power, receive their mandate from the community, in which the creative Spirit is at work, and no more from an imaginary God in the highest, who via his only begotten Son and through him via the popes and their Curia would let descend some part of his power on the hierarchs. And these reserve that power for their own male half of mankind. But in the new view there's no reason for that inequality. Therefore it plays not any longer a role, whether the person that the community invests with authority is male or 
female. And to appeal to the Bible (that does by the way not pronounces itself on that subject) to oppose that equality, is useless, for the Bible is not a book of divine oracles, but depends from the culture in which the authors lived, and in that culture the woman played almost no role.

\section{e. The end of the priesthood.}

With the pre-modern hierarchy disappears also the priesthood. Priests belong to the world of the religions, where they always were regarded and even venerated as the indispensable mediators between the gods or God and mankind. But for the modern faithful there is no more need of such mediators, because God is the Ultimate Love that expresses itself in all things and above all in us, humans. And would there be such need, we have Jesus and don't need other mediators. The priests exercised their function as mediators primarily by making sacrifices of the offerings the believers brought to them. But sacrifices make unconsciously a caricature of God, as will be shown in $\mathrm{nr}$. 6, where the criticism of the cultic sacrifice, is developed a little longer. At any rate, the community around Jesus had in the two first centuries neither sacrifices nor priests. The two appear together in the third century, when the church tried to legitimate its existence by presenting itself as a religion. For whereas the Judaism in the Roman Empire was accepted as a licit religion, Christianity because it had whether sacrifices nor priests, was considered as an illicit union or club or as a kind of philosophical circle.

But when God is not any longer a Theos in the highest, there is of course no more need of priests. There is still more. The new image of God does away with the idea of which the Christian past is full, that God in the highest should by means of human representatives, the popes and the bishops, select and appoint men (never women) and endow them with the magical power, of which no other human disposes, to change with a particular formula bread in a human body and wine in human blood. 
Consequently an image of God that is accessible for the modernity, does not let room for the so called consecrations or ordinations of priests, that should elevate men (never women) to a level that for the other humans is inaccessible. So instead of priests, modern faithful know only community leaders, men or women indistinctly, judges suited to animate the faith in Jesus and through him in God, and therefore chosen and appointed by the community.

\section{g. The end, not of the religious rituals, but of the sacraments.}

This statement will provoke an outcry of protest. But it is the quite inevitable consequence of the new image of God and the farewell to religion. Sacraments indeed are rituals at the occasion of which God in the highest is thought to intervene with healing and blessing. Of this healing and these blessing, it's true, we don't see or feel anything, so we must believe that they happen, and they happen only if a number of prescriptions are observed. But if there is no such God in the highest, of course nothing happens at all. That is very bad news for our romancatholic church, that gives the sacraments a so central place in the Christian life, that it even holds that our eternal salvation depends from them.

Of course, humans need rituals (chimps and bonobo do not) because they need to meet often the holy depth of the daily reality. And rituals manage that, just because they don't serve as means to attain some practical goal, are not useful, the category of usefulness belonging justly to the surface of life. So every culture has spontaneously developed its own rituals, both religious and others, The church too has developed rituals. She calls them sacramentalia. Seven of these she calls sacraments.

These sacraments have begun as church rituals with a rich symbolical content. Think e.g. of baptism originally a bath that evoked renewing, rebirth. But they have gradually lost their symbolic expressivity. To blame for this is the premodern theological error that the only important thing in the sacrament is the intervention of God in the highest with his saving grace, not what we, unimportant 
humans, do. So the sacramental rites have been reduced little by little to the absolute minimum that was required in order that the Theos could come in action. The baptismal bath became a handful of water over the head of a baby, the bread became a paper-thin host that hardly can be called bread. So the sacraments became mere signals addressed to heaven that it could open its holy floodgates.

What will then replace advantageously those signals, that are regarded without reason as triggering the healing intervention of God in the highest? New inspiring rituals, that can enrich, enlighten, heal us, not by a divine intervention from the outside but by fostering by their own symbolic force our humanisation. The new image of God requires hence that we create new rituals or renew the existing ones, and create so a new liturgy, of which will treat point 8.

\section{h. The end of the sacrifice of the Mass.}

That new image of God means also the farewell to the so called sacrifice of the Mass and to everything that in the liturgy of the Mass recalls the idea of sacrifice. And this is a whole lot. Sure, Rome forbids explicitly to deny the sacrificial character of the Mass and to alter any word in the prescribed texts. Never mind, we have to look unconditionally for another concept and for other texts. Indeed, the concept of cultic sacrifice supposes an anthropomorphic God, whose favour, like that of human authorities, one can try to win with the aid of presents. In the social life and in politics such attempts are frowned upon and even condemned as bribing and corruption. But sacrifices are the religious equivalent of that bribing.

But if we stop tempting to bribe God in the highest and say farewell to the traditional interpretation of the Eucharist as a sacrifice, by which other and better interpretation can we replace it? What becomes the Mass in the light of a new image of God? It becomes the inspiring ritual memory of the symbolic gesture with which Jesus as a sign of farewell with the aid of bread and wine made clear his desire to feed his disciples with the best of himself. This ritual memory should be 
an appeal to do in the daily life as Jesus has done in the Last Supper, i.e. to be there for our fellow humans, to become like bread and wine for them.

The whole magic doctrine of the transsubstantiation that the Middle Ages have developed, has to be discarded too, because it can only be held, if one believes that there is a God in the highest, who in the moment that a priest pronounces some magic words, miraculously intervenes to change the nature of things. If something really changes, is it not the bread, for this rests bread, but the signification we give the bread. Before, it was only food that laid in the bakery and could be bought, now for the faithful it becomes the symbol of the presence of Jesus in the community, who calls by that symbol upon all the members of that community to be and to do like he is and does. In two ways he is present there: really present in the hearts of the faithful community, for faith in him and through him in God means real unity with him, and symbolically present in the bread and the wine. But a symbolic presence too is a kind of real presence. For what is not real, is not existing either.

\section{i. The end of the liturgy as a whole of rules of protocol.}

As has been said, the new image of God, calls for a new liturgy, and not only for the Eucharist. The actual liturgy is a kind of protocol, that unconsciously copies the protocol that in past ages (also in some measure still today) one had to observe, if he approached a king or a pope. As if God were a king that sits enthroned in heaven and had issued himself all those liturgical prescriptions. That protocol prescribes meticulously what the celebrating priest has to put on in order to appear before God, which texts he has to read aloud, which prayers he has to say, which gestures he has to make, such as to fold his hands or to rise hem to heaven or to kneel or bow down to moisten his fingertips, to swing the censer, etc and when precisely this all has to be done.

In a pre-modern belief that protocol is considered as the express Will of God, so that one burdens himself with guilt, if he does not observe it careful. But in the 
light of the new image of God as the Ultimate, all penetrating Love, it becomes senseless. By what should it be replaced? By reunions of prayer of the faithful in which they try (or the president of the reunion tries) to express a well as possible, their union with Jesus and through him with God. And they should do that with words and images and gestures of their own time, and not any longer with those of the early Middle Ages as it is the case in the pre-modern liturgy. And in an old peoples home they should do that with other words and forms than for a youth group. And in black Africa with others than in Rome.

\section{j. The end of supplication and of intercession.}

The new image of God means also a farewell to the prayer of supplication. For the creative Ultimate Love is by no means an anthropomorphic and omnipotent ruler, whom one could move, by beseeching him long enough, to intervene in the course of the human affairs, what means to switch of for a brief moment the inflexible natural laws. But if he cannot intervene anyway, it makes no sense to invocate his help. That Jesus exhorts us to beseech God, proves only that also he belonged to the pre-modern world, in which everybody thought that God that could intervene at will and didn't know that this would mean the collapse of the universe. The only form of supplication that makes sense, is praying that our love may grow. Then it is the Ultimate Love itself that inspires us that desire and if we respond to that impulse by praying that we may love more, we let this love enter us.

The farewell to the prayer of supplication means at any rate the end of invoking the intercession of the saints. For to invoke them is a kind of square, for it is to attempt to move them to attempt to move the divine ruler, whom we think we cannot move by ourselves because we are too insignificant in his eyes. This invoking of the saints is a very human reaction, but makes a caricature of the Ultimate Love. For $\mathrm{He} / \mathrm{She} / \mathrm{It}$ is not a for us inaccessible ruler who can be approached only with the help of go-betweens. It is interesting to know that till 
about the end of the first millennium the official prayers of the church don't mention the intercession of the saints.

What replaces then that very human praxis of the prayer of supplication, with or without intercessors, that stems from time immemorial, as humans felt themselves confronted with invisible powers they feared and in the same time the help of which they needed, and did not yet know what was really the matter? A spirituality of abandon, born from the conscience that the Ultimate Love urges us to further humanisation, and that we have nothing else to do as to follow its impulse. Prayer of supplication makes only sense, if it springs from our essential need, our lack of love, and is not a call for things that are accidental and transitory, but a desire that the Love, that is God, may fill us more and more. For then is it the Spirit that cries in us to God, as St Paul says in Rom. 8:26.

\section{k. The waning of the so called vertical dimension of the faith.}

That new image of God means also the waning of the traditional emphasis on piety and obedience That emphasis suggests too clear that one sees God as a ruler in the highest, a view that marks the pre-modern Christianity. Should what replace that? By an emphasis on the horizontal dimension, that means on care, on service, on selfless commitment for a more human society, called by Jesus the Kingdom of God. Then God, the Ultimate Love, cannot but push the cosmos, that is his evolving self-expression, towards more love, and the more this happens, the more he reigns.. And he pushes us humans towards that goal by urging us to give up our ego and to unite us with our fellow humans.

That is why the essential task of a Christian consist in the commitment for mankind and cosmos, the so called diaconia, much more than in the liturgy. Jesus himself lets us know that, where he gives the reconciliation with the "brother" priority to the making of sacrifices, and where he does not at all agree with them that call "Lord, Lord", but only with them that do the will of his Father. And the 
will of his Father is his formulation of that was has been called here the urging of the Ultimate Love.

\section{Conclusion}

What rests after that all of the millenarian catholic monument, if one gives up the Theos and factually becomes an a-theistic faithful? Don't wonder: the essence rests. And that is not the formulation of the creed, not a book with infallible words of God himself, not the ten commandments, not an autocratic hierarchy, not the sacraments and the priesthood and the sacrifice of the Mass and the minute rules of a liturgical protocol, not the prayer of supplication and not the obedience to church rules. It is the conscience that we participate in a cosmos that is the always further evolving self-expression of a creative Spirit, who is Love, together with the willingness to let move us by that love, following Jesus, whom we know as the forever living, because he was and is the totally loving. For someone who thinks so, of course it is difficult to feel at home in the pre-modern church life with its conceptions and uses and forms of piety. But he should not leave the community. He should consider that the pre-modern way of faith has been the way that has guided countless Christians to a deep union with the Ultimate Love and to an outstanding degree of humanity. It remains such a way for all our fellow Christians who don' yet have seen that times have changed.

It has seemed in the beginning that faith and modernity exclude each other. Not only they don't, but even they complete and enrich each other. The Christian faith enriches the modernity by freeing her von her blindness to a Reality that transcends us absolutely and in the same time embraces us. Without that insight, the humanist confession of the absolute value of the human person and the human rights misses its indispensable fundament. For without the creative Absolute love that urges the cosmos and mankind to a further evolution, the human race is only a little more evolved branch of the mammal family that has not such absolute 
value. And that evolution to homo sapiens would be only the accidental result of blind mutations and natural selection during astronomic long periods. Moreover the human person with his inviolable rights would only be the result of the organic evolution of a zygote, that in the view of the modern humanism has no rights at all. Where from could then this absolute value come?

The modernity on the other hand enriches our faith and completes it, by freeing it from the anthropmorphic image of a Theos in the highest, that it has inherited from prehistoric generations and that it has not yet risked to give up, although it was only the consequence of sheer ignorance. That image is in reality a screen between us and the Ultimate Love. At best it is a finger which refers us to Him/Her/It. And we shall look to that Ultimate Reality and not to that finger. Moreover, if the cosmos is the self-expression of the Mystery that is God, then I too belong to that self-expression and God becomes in an unconceivable way near to me, becomes deeper myself than my deepest self. And so I can find him, who is my deepest need, always and everywhere. At the same time modernity purifies the traditional faith from the intolerance, the striving for power, the fanaticism, the superstitions, the illusions and fears that proliferate in all religions. And it enriches faith by its insistence on the existential, the intramundane, the rational, the real. Modernity and faith go indeed together. And that is good so. For thy need each other very much. 